\title{
Hubungan Bentuk Telapak Kaki, Panjang Tungkai Dengan Daya Ledak Otot Tungkai Terhadap Atlet Kids Athletics Putri 11-14 Tahun Rawamangun
}

\author{
Iwan Hermawan, Tarsono \\ Correspondence: Fakultas Ilmu Keolahragaan, Universitas Negeri Jakarta, Jakarta, \\ Indonesia \\ E-mail: ihermawan@unj.ac.id
}

\begin{abstract}
Abstrak
Hubungan gerakan merupakan salah satu ciri-ciri koordinasi yang sangat penting dan perlu dipahami oleh pelaku olahraga, karena hubungan gerakan merupakan salah satu dasar untuk dapat menguasai bentuk-bentuk keterampilan motorik olahraga. Hubungan gerakan merupakan suatu proses transfer impuls tenaga dari suatu bagian tubuh ke bagian tubuh yang lain atau proses transfer impuls dari suatu alat gerak ke alat gerak yang lain, sehingga terjadi hubungan gerakan. Penelitian ini dilakukan dengan pendekatan kuantitatif dengan teknik studi korelasi multivariat, yaitu suatu penelitian untuk mengumpulkan data yang diperoleh dengan mengukur dan mencatat hasil dari pengukuran yang terdiri dari bentuk telapak kaki, panjang tungkai dan daya ledak otot tungkai. Hasil penelitian ini sebagai berikut: (1) Terdapat hubungan yang signifikan antara bentuk telapak kaki $\left(X_{1}\right)$ dengan daya ledak otot tungkai $(Y)$ pada atlet kids atletik putri P.A Rawamangun Atletik Center usia 11-14 tahun, (2) Terdapat hubungan yang signifikan antara panjang tungkai (Y) dengan daya ledak otot tungkai (Y) pada atlet kids atletik putri P.A Rawamangun Atletik Center usia 11-14 tahun, (3) sTerdapat hubungan yang signifikan antara bentuk telapak kaki $\left(X_{1}\right)$ dan panjang tungkai $\left(X_{2}\right)$ dengan daya ledak otot tungkai (Y) pada Atlet kids atletik putri P.A Rawamangun Atletik Center usia 11-14 tahun.
\end{abstract}

\section{Kata Kunci: Bentuk Telapak Kaki, Panjang Tungkai}

\section{Pendahuluan}

Atletik adalah salah satu cabang olahraga tertua yang telah dilakukan oleh manusia sejak zaman purba hingga sekarang. Atletik sebagai mother of sport memiliki banyak nomor - nomor perlombaan. Dalam Olimpiade, atletik merupakan cabang olahraga yang memperebutkan medali paling banyak, hal ini muncul karena atletik mempunyai cabang olahraga yang banyak, terdiri dari 4 nomor yaitu; jalan, lari, lempar dan lompat. Dari tiap-tiap nomor tersebut di dalamnya terdapat beberapa nomor yang dilombakan. Untuk nomor lari terdiri dari: lari jarak pendek, jarak menengah, jarak jauh atau marathon, lari gawang, lari sambung dan lari lintas alam. Nomor lompat meliputi lompat jauh, lompat tinggi, lompat jangkit, lompat tinggi 
galah. Nomor lempar meliputi lempar cakram, lempar lembing, tolak peluru dan lontar martil.

Hubungan gerakan merupakan salah satu ciri-ciri koordinasi yang sangat penting dan perlu dipahami oleh pelaku olahraga, karena hubungan gerakan merupakan salah satu dasar untuk dapat menguasai bentuk-bentuk keterampilan motorik olahraga. Hubungan gerakan merupakan suatu proses transfer impuls tenaga dari suatu bagian tubuh ke bagian tubuh yang lain atau proses transfer impuls dari suatu alat gerak ke alat gerak yang lain, sehingga terjadi hubungan gerakan.

Banyak komponen biomotori yang dapat diperhatikan, diantaranya kordinasi, kelentukan, power atau daya ledak, kekuatan, kelincahan, dan salah satu faktor yang juga mempengaruhi yaitu bentuk telapak kaki, Bentuk telapak kaki atau lebih sering dikenal dengan istilah bentuk telapak kaki, merupakan suatu bentuk komponen tubuh alamiah, bentuk telapak kaki tidak dapat kita bentuk sesuai keinginan kita, ini merupakan bawaan sejak lahir.

\section{Pustaka}

Telapak kaki adalah bagian bawah kaki. Telapak kaki dibagi menjadi 3 bagian, telapak kaki depan, tengah dan belakang. Kaki berfungsi sebagai organ penyangga tubuh, pengatur keseimbangan, dan untuk mobilitas gerak. Arkus atau sudut kelengkungan pada kaki berfungsi untuk menyokong kaki dalam pergerakan dan menopang berat badan. Jika ditinjau dari cara kerjanya, sudut kelengkungan kaki dipengaruhi oleh tiga mekanisme utama, yaitu:

a. Hubungan antara tulang tarsal dan metatarsal.

b. Hubungan antara beberapa ligamen dari plantar aponeurosis hingga ligamen plantar anterior.

c. Otot-otot penunjang pada kaki.

Gambar di bawah ini adalah gambar ilustrasi telapak kaki yang mungkin didapatkan pada orang pada umumnya.

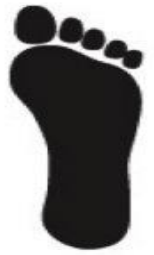

Low Arch

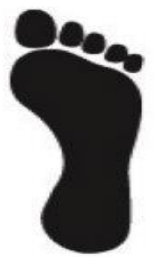

Normal Arch

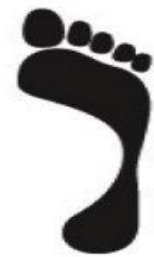

High Arch

Gambar 1. Jenis kaki berdasarkan tipe kelengkungan kaki

Dari 3 tipe arkus pada kaki di atas, perbedaan dari masing-masing arkus kaki tersebut terdapat pada sisi medial-longitudinal kaki. Hal ini akan sangat mempengaruhi aktivitas fisik. Sudut kaki medial-longitudinal tersebut dibentuk oleh tulang kalkaneus, talus, tulang kuineiformis dan tulang metatarsal sisi medial. Bukan 
hanya tulang yang mempengaruhi bentuk dari arkus tersebut, terdapat beberapa ligamen dan juga otot yang berperan serta dalam pembentukan sudut kaki mediallongitudinal tersebut, yaitu ligamen kalkaneonavikular anterior, fascia plantaris, tibialis posterior, fibularis longus, fleksor digitorum longus, fleksor hallucis longus dan fibularis, otot soleus dan gastrocnomius.

Telapak kaki memiliki dua lengkungan longitudinal, tetapi bukan suatu karya tukang batu melainkan menyerupai suatu pegas daripada suatu lengkungan.

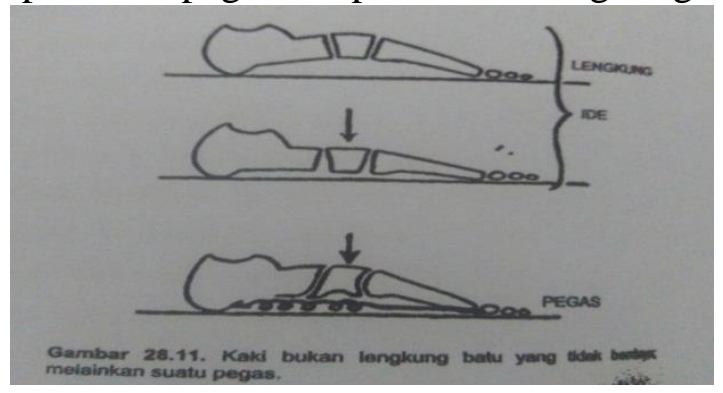

1. Normal Arch

Gambar 2. Lengkung Pegas Telapak Kaki

Kaki jenis ini memiliki sudut kelengkungan yang normal pada bagian tengah atau foot sehingga pada bagian ini terdapat lebar yang cukup. Dalam berlari beban tubuh akan jatuh pada sisi lateral dari samping luar atau rare foot setelah itu bergulir ke arah medial dengan sedikit pronasi ke sisi mid foot sehingga hentakan dapat diredam. Manusia dengan tipe kaki dan kelengkungan seperti ini akan berlari secara ergonomis dan efisien.

2. Low Arch

Tipe ini disebut juga flat foot, pronator foot, atau lebih sering disebut kaki bebek. Saat berlari atau berpijak, kaki jenis ini akan meninggalkan jejak hampir seluruh telapak kaki ditandai dengan bagian mid foot relatif sama lebar dengan kaki bagian depan atau fore foot. Biasanya akan terjadi kecenderungan tungkai melengkung ke arah medial saat berdiri. overpronasi saat berlari, overpronasi saat berlari terjadi pada sisi luar dari rare foot dan berat badan bergulir ke arah medial secara simultan. Kelainan bentuk telapak kaki ini menyebabkan berbagai masalah seperti tarikan yang ekstra pada jaringan ikat telapak kaki (fascia plantaris), otot-otot bagian dalam kaki dan tungkai serta cenderung membuat lutut berbentuk " $X$ ". Kondisi tersebut menyebabkan gangguan biomekanika dan ketidak-seimbangan otototot gerak bagian bawah.

\section{High Arch}

Tipe ini disebut juga $C$-shaped foot. Kaki dengan tipe sudut kelengkungan ini, memberi indikasi supinasi kaki dan rentan untuk risiko jatuh karena sudut kelengkungan yang sangat dalam sehingga hubungan antara fore foot dan mid foot tidak stabil. Bagian mid foot akan menjadi sangat sempit. Pembebanan berat badan saat berlari pada kelainan ini terjadi pada bagian caput dari metatarsal. Bentuk 
tungkai terkadang membentuk huruf "O". Pada bentuk telapak kaki ini dapat meningkatkan resiko terkilir pada angkle bagian luar dan nyeri pada tulang-tulang kaki saat berlari dan juga melompat. Kondisi ini akan memberikan hambatan pada anak dalam melakukan lompatan. Berikut adalah contoh gambar cekungan telapak kaki :

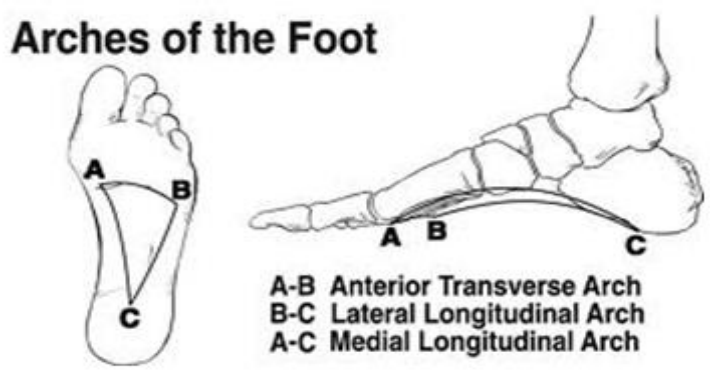

Gambar 3. Lengkung telapak kaki

Pada gambar diatas terlihat, yaitu cekungan pada bagian dalam (arah yang memanjang A-C) bagian luar (arah yang memanjang B-C) dan bagian depan (arah yang menyamping A-B). Jika pada cekungan ini mengalami penurunan yang disebabkan oleh melemahnya otot, maka keseimbangan telapak kaki akan terganggu, sehingga dapat menyebabkan tekanan yang berlebihan, perubahan posisi (deformasi), yang akhirnya dapat menimbulkan rasa sakit. Bagi telapak kaki yang memiliki cekungan yang terlalu tinggi juga akan memberikan pergerakan pegas menjadi lebih kaku dan akan terjadi juga perubahan antropometri dari bentuk tungkai.

Panjang tungkai sebagai salah satu anggota gerak bawah memiliki peran penting dalam unjuk kerja olahraga. Sebagai anggota gerak bawah, panjang tungkai berfungsi sebagai penopang gerak anggota tubuh bagian atas, serta penentu gerakan baik dalam berjalan, berlari, melompat maupun menendang. Panjang tungkai adalah jarak vertikal antara telapak kaki sampai dengan pangkal paha yang diukur dengan cara berdiri tegak. Panjang tungkai sebagai bagian dari postur tubuh memiliki hubungan yang sangat erat dalam kaitannya sebagai pengungkit disaat melompat.

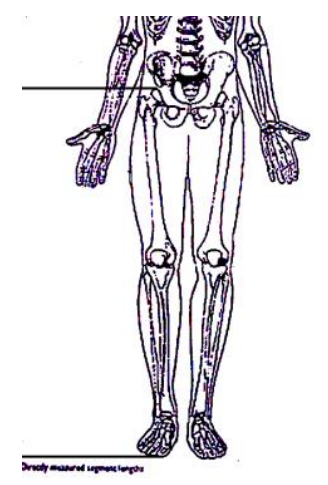

Gambar 1. Letak Pengukuran Panjang Tungkai 
Anggota gerak bagian bawah terdiri dari: Tulang Panggul, Femur, Patela, Tibia, Tulang-tulang Kaki. Struktur otot yang berada di tungkai adalah (1) otot-otot pangkal paha, (2) otot-otot tungkai atas, (3) otot-otot tungkai bawan, (4) otot-otot kaki. Adapun yang termasuk dalam tulang anggota badan bawah dibedakan menjadi:

a) Tulang-tulang gelang panggul (cingulum extremitas inferior)

b) Tulang-tulang anggota badan bawah yang besar (skeleton extremitas

inferior liberae). Terdapat rumus fisika yang menjelaskan teori bahwa panjang (panjang tungkai) akan mempengaruhi hasil gaya (daya ledak) yaitu rumus Torsi sebagai berikut

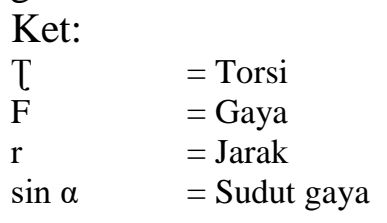

$$
T=F \cdot r \cdot \operatorname{Sin} \alpha
$$

Komponen yang dibutuhkan mendukung jangkauan langkah yang panjang di antaranya adalah kemampuan biomotor, teknik, koordinasi, serta proporsi fisik yang bagus di dalamnya, sehingga semakin panjang tungkainya akan dapat diikuti dengan jangkauan langkah yang semakin panjang sehingga waktu yang diperlukan untuk menempuh suatu jarak tertentu dalam lari akan semakin pendek, dengan kata lain waktu tempuhnya mejadi lebih cepat dan energi yang dikeluarkan akan semakin sedikit. Dengan demikian panjang tungkai yang penulis maksudkan adalah jarak antara pangkal paha sampai dengan pangkal kaki seseorang. Istilah ini selanjutnya akan dipergunakan dalam penulisan ini.

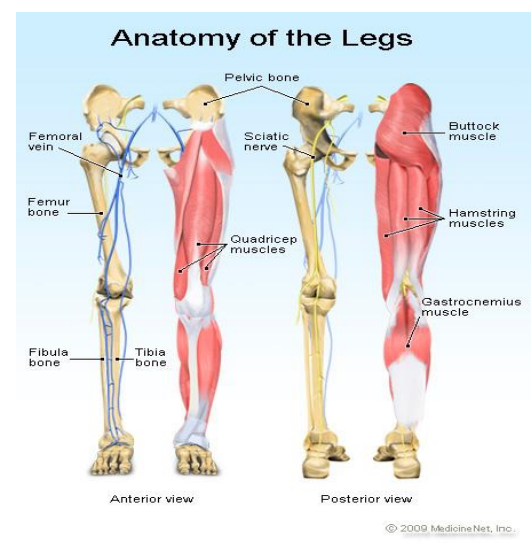

Gambar 5. Otot dan Tulang Tungkai Manusia

Power merupakan perpaduan dua unsur komponen kondisi fisik yaitu kekuatan dan kecepatan. Kualits power akan tercermin dari unsur kekuatan dan kecepatan yang dalam pelaksanaanya dilakukan dengan eksplosif dalam waktu yang sesingkat mungkin. Dalam ilmu keolahragaan power juga sering disebut dengan daya ledak (explosif power) atau muscular power. Daya ledak otot tungkai atau yang 
disebut juga daya eksplosif otot (muscle explosive) yang maksudnya adalah kemampuan otot atau sekelompok otot untuk melakukan kerja secara eksplosif pada tungkai.

Jarak antara kontraksi otot sampai obyek adalah hal yang diperhitungkan dalam kerja power. Perhitungan dapat dirumuskan sebgai berikut:
a) Power $(P)=\frac{\operatorname{work}(w)}{\text { time }(\text { time })}$ dan $($ Work $(w)=$ Force $(f) x \operatorname{distance}(d))$
b) $\operatorname{power}(P)=\frac{\operatorname{Force}(f) x \operatorname{distance}(d)}{\operatorname{time}(t)}$ dan $\left(\operatorname{Velocity}(v)=\frac{\operatorname{distance}(d)}{\text { time }(t)}\right)$
c) $\operatorname{Maka} \operatorname{Power}(P)=\mathrm{f} \mathrm{x} \mathrm{v}^{-}$

Menurut definisi yang sudah diutarakan dapat dilihat bahwa power memiliki fungsi yaitu kontraksi otot kekuatan maksimal dengan kecepatan maksimal dalam melakukan lompatan demi mencapai daya ledak yang maksimal. Maka power otot tungkai adalah kemampuan otot tungkai untuk melakukan tolakan atau dorongan keatas secara eksplosive mulai dari persiapan tolakan posisi setengah jongkok hingga bagian akhir kaki meninggalkan papan tolakan.

Pada tahun 2001 Inernational Association of Athletics Federation (IAAF) yang merupakan induk organisasi atletik dunia mengembangkan suatu konsep baru atletik yang secara unik disesuaikan dengan kebutuhan perkembangan anak, konsep ini mulai sekarang dan selanjutnya diberi nama "IAAF Kids Athletic". Konsep yang dimaksud adalah untuk membawa kegembiraan dalam bermain pada cabang olahraga atletik. Kegiatan baru yang memungkinkan anak-anak untuk menemukan gerakan aktifitas dasar. Permaianan dalam cabang olahraga atletik akan menyediakan anakanak dengan kesempatan untuk mempergunakan dengan baik praktek atletik yang menguntungkan dalam kaitannya dengan kesehatan, pendidikan dan kepuasan diri.

Kids Athletic RACe yang dibuat untuk anak-anak jenjang usia antara 5 hingga 14 tahun memiliki banyak aktifitas yang menyenangkan. Dan semua adalah gerakan fundamental, seperti jalan, lari, lempar, lompat. Anak-anak pada usia tersebut biasanya diperkenalkan pada semua nomor cabang yang ada pada atletik, dari gerakan kordinasi untuk berlari, kordinasi melempar, kordinasi melompat. Setelah anak lulus melewati tahap pertama kemudian anak akan mempelajari tingkatan selanjutnya yang kemudian mendapatkan pelatihan yang lebih serius tetapi tetap menyenangkan, lalu meningkat lagi kepada tahap dimana anak mendapatkan spesialisasi pada nomor-nomor yang cocok untuk anak dengan dilihat dari analisi biomekanika dan fisiologi anak. Aktifitas latihan yang dilakukan dalam kids athletic bervariasi, seru dan menyenangkan. Karena dilakukan dengan senang gembira seperti sedang bermain, bukan seperti program latihan berat yang dilakukan pada atlet umumnya.

Masa remaja sering disebut dengan masa "puber". Istilah "puber" dapat dipakai untuk anak yang menunjukan perilaku yang menyulitkan orang lain. Pubertas berarti kelaki-lakian dan menunjukan kedewasaan yang dilandasi oleh sifat kelakilakian dan ditandai oleh kematangan fisik. Pada masa ini terlihat perubahan- 
perubahan jasmaniah berkaitan dengan proses kematangan jenis kelamin. Terlihat pula adanya perkembangan psikososial berhubungan dengan berfungsinya seseorang dalam lingkungan sosialnya.

Menururt Hurlock remaja awal (12/13 th - 17/18 th), remaja akhir (17/18 th $21 / 22$ th). WHO menyatakan walaupun definisi remaja utamanya didasarkan pada usia kesuburan (fertilitas) putri, namun batasan itu juga berlaku pada remaja pria, dan WHO membagi kurun usia dalam dua bagian yaitu remaja awal $10-14$ tahun dan remaja akhir 15 - 20 tahun.

Perubahan-perubahan dalam penampilan gerak pada masa adolesensi cenderung mengikuti perubahan-perubahan dalam ukuran badan, kekuatan, dan fungsi fisologis. Perbedaan-perbedaan dalam penampilan keterampilan gerak dasar antara kedua jenis kelamin semakin meningkat, anak laki-laki menunjukan peningkatan yang tidak berarti.

Umur skeletal atau menstruasi berhubungan dengan umur kronologis dan setiap hubungan selalu ditunjukan dengan penampilan gerak. Umumnya penampilan gerak anak anak perempuan dalam keterampilan dasar cenderung menurun sebelum mencapai kematangan biologis, kira-kira 3 tahun sebelum kematangan skeletal. Sebaliknya anak laki-laki terus mengalami peningkatan penampilan geraknya dengan bertambahnya kematangan skeletal. Kecepatan matang secara biologis anak laki-laki ditunjukan adanya beberapa hubungan dengan penampilan gerak. Umumnya anak laki-laki masa puber meningkat secara terus-menerus dan teratur dalam lari dan melompat, tetapi sedikit terlambat dalam lemparan. Hal ini berhubungan dengan serangkaian pertumbuhan fisik, seperti tungkai yang memanjang, pinggul yang melebar sebelum pengembangan bagian pundak.

Adapun yang menjadi konsep berfikir dalam penelitian ini adalah Dalam dunia olahraga bentuk telapak kaki merupakan bagian penting dan dapat dijadikan sebagai salah satu pemandu bakat. Dalam dunia atletik, bentuk telapak kaki memiliki banyak pengaruh terhadap lari dan juga melompat. Oleh karena itu, bentuk telapak kaki adalah salah satu faktor utama yang harus diperhatikan karena diduga bentuk tepak kaki yang normal membantu memberikan tolakan awal yang dapat mempengaruhi kualitas ketinggian lompatan.

Kemudian teori yang telah disebutkan didalam hakikat bentuk telapak kaki yang menyatakan peran lengkungan telapak kaki yang normal atau 'normal arch' adalah untuk menciptakan keselarasan yang optimal bagi anggota gerak tubuh bagian bawah, panggul, dan punggung bawah karena terdiri dari banyak tulang yang dihubungkan dengan ligamentum dan secara aktif ditahan oleh tendon-tendon fleksible yang menambah kapabilitas penahan berat dan gaya pegas kaki berfungsi sebagai peredam benturan kaki terhadap beban tubuh, tetapi juga sebagai batu loncatan pada saat berlari maupun melompat.

Selain bentuk telapak kaki, panjang tungkai juga memiliki peranan penting terhadap daya ledak, kualitas dan kuantitas otot - otot pada paha akan mempengaruhi daya ledak pada otot tungkai. Semakin baik kualitas otot - otot paha maka akan baik pula daya ledak otot tungkainya begitu juga dengan kuantitas pada tungkai, semakin 
baik panjang tungkai maka akan semakin baik juga power yang akan dihasilkan. Maka diduga panjang tungkai memiliki hubungan positif dengan keterampilan melompat pada pengukuran daya ledak otot tungkai.

Dengan melihat faktor-faktor tersebut maka sangatlah penting untuk mengetahui hasil penelitian ini, sudah banyak paradigma - paradigma yang belum di teliti secara ilmiah namun sudah menjadi panutan dalam dunia pemandu bakat atau sering disebut talent scouting, ini merupakan hal yang harus diluruskan, karna apabila para pemandu bakat salah mengarahkan, maka atlet tidak akan berkembang luas, dan akan sulit bersaing di kancah nasional maupun internasional. talent scouting merupakan salah satu sport science dan harus dibuktikan secara ilmiah.

\section{Metode}

Penelitian ini dilakukan dengan pendekatan kuantitatif dengan teknik studi korelasi multivariat, yaitu suatu penelitian untuk mengumpulkan data yang diperoleh dengan mengukur dan mencatat hasil dari pengukuran yang terdiri dari bentuk telapak kaki, panjang tungkai dan daya ledak otot tungkai. Variabel bebas dalam penelitian ini adalah bentuk telapak kaki, dan panjang tungkai. Variabel terikatnya adalah daya ledak otot tungkai. Desain yang di gunakan:

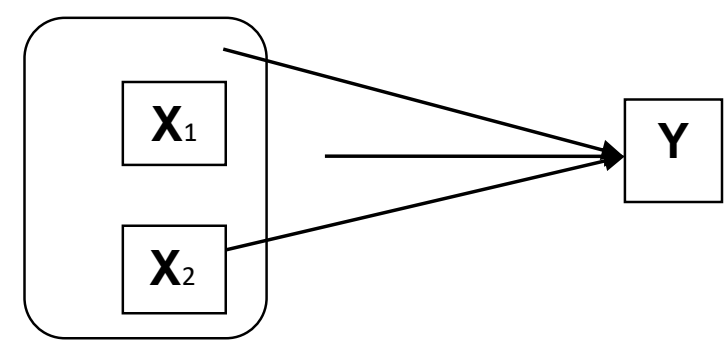

Gambar 2. Desain penelitian

Keterangan:

$$
\begin{array}{ll}
X_{1} & \text { : Bentuk telapak kaki } \\
X_{2} & \text { : Panjang tungkai } \\
\mathrm{Y} & \text { : Daya ledak Otot Tungkai }
\end{array}
$$

\section{Pembahasan}

\section{Hubungan Bentuk telapak kaki dengan Daya Ledak Otot Tungkai}

Hubungan bentuk telapak kaki dengan keterampilan daya ledak otot tungkai dinyatakan oleh persamaan regresi $\hat{Y}=24,5+2,13 X_{1}$. Artinya keterampilan daya ledak otot tungkai dapat diketahui atau diperkirakan dengan persamaan regresi tersebut, jika variabel bentuk telapak kaki $\left(\mathrm{X}_{1}\right)$ diketahui. Hubungan bentuk telapak kaki $\left(\mathrm{X}_{1}\right)$ dengan keterampilan daya ledak otot tungkai (Y) ditunjukan oleh koefisien 
korelasi ry $1=0,634$. Koefisien korelasi tersebut harus diuji terlebih dahulu mengenai keberartiannya, sebelum digunakan untuk mengambil kesimpulan.

\section{Hubungan Panjang tungkai Dengan Keterampilan Daya ledak otot tungkai}

Hubungan panjang tungkai dengan keterampilan daya ledak otot tungkai dinyatakan oleh persamaan regresi $\hat{Y}=-66,72+1,25 X_{2}$. Artinya keterampilan daya ledak otot tungkai dapat diketahui atau diperkirakan dengan persamaan regresi tersebut, jika variabel panjang tungkai $\left(\mathrm{X}_{2}\right)$ diketahui. Hubungan panjang tungkai $\left(\mathrm{X}_{2}\right)$ dengan keterampilan daya ledak otot tungkai $(\mathrm{Y})$ ditunjukan oleh koefisien korelasi ry $1=0,685$. Koefisien korelasi tersebut harus diuji terlebih dahulu mengenai keberartiannya, sebelum digunakan untuk mengambil kesimpulan.

\section{Hubungan Bentuk Telapak Kaki dan Panjang Tungkai Terhadap Daya Ledak Otot Tungkai}

Hubungan bentuk telapak kaki $\left(\mathrm{X}_{1}\right)$ dan panjang tungkai $\left(\mathrm{X}_{2}\right)$ terhadap daya ledak otot tungkai $(Y)$ dinyatakan oleh persamaan regresi $\hat{Y}=-40,074+1,319 X_{1}+$ $0,819 X_{2}$. Sedangkan hubungan ketiga variabel tersebut dinyatakan oleh koefisien korelasi ganda Ry1-2 = 0,766. Koefisien korelasi ganda tersebut, harus di uji terlebih dahulu mengenai keberartiannya sebelum digunakan untuk mengambil kesimpulan.

Berdasarkan dari hasil penelitian yang telah dilakukan, maka dapat ditemukan hasil penelitian menunjukkan:

Pertama, Terdapat hubungan bentuk telapak kaki dengan daya ledak otot tungkai, dengan persamaan garis linier $\hat{\mathrm{Y}}=24,5+2,13 \mathrm{X}_{1}$, koefisien korelasi (ry1) $=$ 0,634, yang berarti tingkat hubungannya masuk dalam kategori tinggi. Koefisien determinasi $\left(\right.$ ry $\left.^{2}\right)=0,40$ yang berarti variabel bentuk telapak kaki memberikan sumbangan dengan keterampilan daya ledak otot tungkai sebesar $40 \%$.

Kedua, terdapat hubungan panjang tungkai dengan keterampilan daya ledak otot tungkai, dengan persamaan garis linier $\hat{Y}=-66,72+1,25 X_{2}$, koefisien korelasi (ry1) $=0,685$, yang berarti tingkat hubungannya masuk dalam kategori tinggi. Koefisien determinasi $\left(\right.$ ry $\left.1^{2}\right)=0,470$, yang berarti variabel panjang tungkai memberikan sumbangan terhadap keterampilan daya ledak otot tungkai sebesar $47 \%$.

Ketiga, terdapat hubungan bentuk telapak kaki dan panjang tungkai dengan keterampilan daya ledak otot tungkai, dengan persamaan garis linier $\hat{Y}=-40,074+$ $1,319 X_{1}+0,819 X_{2}$, koefisien korelasi Ry1-2 = 0,766, yang berarti tingkat hubungannya masuk dalam kategori tinggi. Koefisien determinasi $(\text { Ry1-2 })^{2}=0,586$ yang berarti variabel panjang tungkai dan bentuk telapak kaki dengan keterampilan daya ledak otot tungkai memberikan sumbangan sebesar 58,60\%.

Dalam penelitian ini panjang tungkai dan bentuk telapak kaki secara bersamasama memberikan kontribusi sebesar $58,60 \%$ pada keterampilan daya ledak otot tungkai. Sisanya sebesar $41,40 \%$ ditentukan oleh faktor lainnya. Faktor-faktor yang dapat mempengaruhi keterampilan daya ledak otot tungkai adalah kekuatan, keseimbangan, kordinasi kaki tangan, dan tinggi badan. Hal lain yang juga akan 
mempengaruhi daya ledak otot tungkai adalah usia latihan atlet. Usia latihan pada sample penelitian ini beragam, dan ditemukan bahwa atlet yang memiliki usia latihan lebih lama akan memiliki daya ledak otot yagn lebih baik daripada atlet yang memiliki usia latihan lebih muda.

\section{Simpulan}

Berdasarkan hasil penelitian, maka peneliti dapat menarik kesimpulan sebagai berikut:

1. Terdapat hubungan yang signifikan antara bentuk telapak kaki (X1) dengan daya ledak otot tungkai (Y) pada atlet kids atletik putri P.A Rawamangun Atletik Center usia 11-14 tahun

2. Terdapat hubungan yang signifikan antara panjang tungkai (Y) dengan daya ledak otot tungkai (Y) pada atlet kids atletik putri P.A Rawamangun Atletik Center usia 11-14 tahun

3. Terdapat hubungan yang signifikan antara bentuk telapak kaki (X1) dan panjang tungkai (X2) dengan daya ledak otot tungkai (Y) pada Atlet kids atletik putri P.A Rawamangun Atletik Center usia 11-14 tahun.

\section{Rujukan}

Arikunto, 2006. Suharsimi, Prosedur Penelitian. Jakarta: PT Rineka Cipta.

Crumpton S, 2015. ACSM information shoes. Selecting and effectively using running, Available from: www.acsm.org

Dutton M, 2012. Dutton's orthopaedic examination evaluation and intervention, 3rd editions. New York: McGraw Hill.

Harsono, 2013. latihan kondisi fisik, komite olahraga nasional indonesia pusat: pusat pendidikan dan penataan Jakarta.

Hurlock, Perkembangan dan Pertumbuhan Pada Masa Remaja. (http://anandapriadmajha.blogspot.com/2013/05/perkembangan-masaremaja.html)

Imam Hidayat, 2010. Buku pedoman, serie: Biomekanika olahraga, Jakarta: pusat ilmu olahraga koni pusat.

Riduwan, 2010. Belajar Mudah Penelitian Untuk Guru, Karyawan Dan Peneliti Pemula. Bandung : Alfabeta

Sugiyanto, Sujarwo, 1993. Perkembangan dan Belajar Gerak. Jakarta: Departemen Pendidikan dan Kebudayaan.

Tim Pengembang MKDK, 2002. Psikologi Perkembangan. Jakarta: MKDK FIP-UNJ 